\title{
Surgery for non-small cell lung cancer: systematic review and meta-analysis of randomised controlled trials
}

\author{
G Wright, R L Manser, G Byrnes, D Hart, D A Campbell

See end of article for authors' affiliations

.....................

Correspondence to: Dr R L Manser, Department of Respiratory Medicine, St Vincent's Hospital Melbourne, Fitzroy, 3065, Victoria, Australia; manserrl@mh.org.au

Received 1 September 2005 Accepted 17 January 2006 Published Online First 31 January 2006

\begin{abstract}
Background: Surgery is considered the treatment of choice for patients with resectable stage I and II (and some patients with stage IIIA) non-small cell lung cancer (NSCLC), but there have been no previously published systematic reviews.

Methods: A systematic review and meta-analysis of randomised controlled trials was conducted to determine whether surgical resection improves disease specific mortality in patients with stages I-IIIA NSCLC compared with non-surgical treatment, and to compare the efficacy of different surgical approaches.

Results: Eleven trials were included. No studies had untreated control groups. In a pooled analysis of three trials, 4 year survival was superior in patients undergoing resection with stage I-IIIA NSCLC who had complete mediastinal lymph node dissection compared with lymph node sampling (hazard ratio estimated at $0.78(95 \% \mathrm{Cl} 0.65$ to 0.93$)$ ). Another trial reported an increased rate of local recurrence in patients with stage I NSCLC treated with limited resection compared with lobectomy. One small study reported a survival advantage among patients with stage IIIA NSCLC treated with chemotherapy followed by surgery compared with chemotherapy followed by radiotherapy. No other trials reported significant improvements in survival after surgery compared with non-surgical treatment.

Conclusion: It is difficult to draw conclusions about the efficacy of surgery for locoregional NSCLC because of the small number of participants studied and methodological weaknesses of the trials. However, current evidence suggests that complete mediastinal lymph node dissection is associated with improved survival compared with node sampling in patients with stage I-IIIA NSCLC undergoing resection.
\end{abstract}

\section{METHODS}

\section{Searching}

A search of electronic databases including MEDLINE (1966 to December 2003), EMBASE (1974 to December 2003), and the Cochrane Central Register of Controlled Trials (CENTRAL) (The Cochrane Library Plus, Issue 4, 2003) was undertaken. Full details of the search strategy are outlined elsewhere. ${ }^{8}$ The journal Lung Cancer was hand searched from 1995 to March 2004, as were abstracts from the annual scientific meetings of the American Association for Thoracic Surgery for 2002 and European Association for Cardiothoracic Surgery for 1999 to

2003. Bibliographies were also searched and authors of primary studies and experts in the field were contacted.

\section{Selection}

RCTs comparing surgical resection with no treatment or nonsurgical treatment in patients with stage I-IIIA NSCLC were assessed. Studies comparing different types of surgery-for example, lobectomy versus limited resection-were also assessed. Trials were considered eligible if they included individuals with histopathologically or cytologically proven stages I-IIIA NSCLC and reported overall or disease specific survival at 2, 3, 4 or 5 years. Trials comparing surgery alone with surgery plus chemotherapy or radiotherapy were excluded.

Two reviewers (RM and DH) independently assessed titles and abstracts from electronic searches and relevant articles were selected for full text review. Studies were selected for inclusion in the review after the full text articles had been assessed by two reviewers (RM and GW). When assessing the eligibility and quality of studies, the reviewers were aware of the authorship and source of publication of the studies.

\section{Validity assessment}

Two reviewers (RM and GW) evaluated the quality of the studies independently with disagreements resolved by consensus. Using the Cochrane approach to allocation concealment, trials were described as having adequate, unclear, or inadequate concealment. ${ }^{\text {The }}$ Thequacy of the method of

Abbreviations: CMLND, complete mediastinal lymph node dissection; NSCLC, non-small cell lung cancer; RCT, randomised controlled trial; SS, systematic sampling; VATS, video assisted thorascopic surgery 
randomisation was also assessed as described by Jadad et al. ${ }^{10}$ The reviewers assessed whether there was blinding of outcome assessment and adequate description of withdrawals. ${ }^{10}$ Finally, an assessment was made as to whether the trial results used intention to treat analysis. ${ }^{11}{ }^{12}$ The authors of included studies were asked to verify assessments of study methodology where possible.

\section{Data extraction}

Data extracted by one of the reviewers (RM) was entered in the Cochrane Collaboration software (Review Manager Version 4.2 for Windows, Cochrane Collaboration, Oxford, UK, 2002). Authors of included studies were asked to confirm the data extracted where possible. A second reviewer (GW) extracted data from graphs, where necessary, for main study outcomes.

\section{Outcome measures}

The main outcomes were overall or disease specific survival at 2, 3, 4 or 5 years. Secondary outcomes included progression free survival or recurrence rates (local, distant or both), postoperative mortality or treatment related death, and tests of respiratory function.

\section{Quantitative data synthesis}

Outcomes were pooled using the Review Manager and a pooled relative risk was calculated with 95\% confidence intervals. Homogeneity of effect sizes among pooled studies was tested using the $\chi^{2}$ statistic for homogeneity with $\mathrm{p}<0.1$ as the level for significance. In the absence of significant

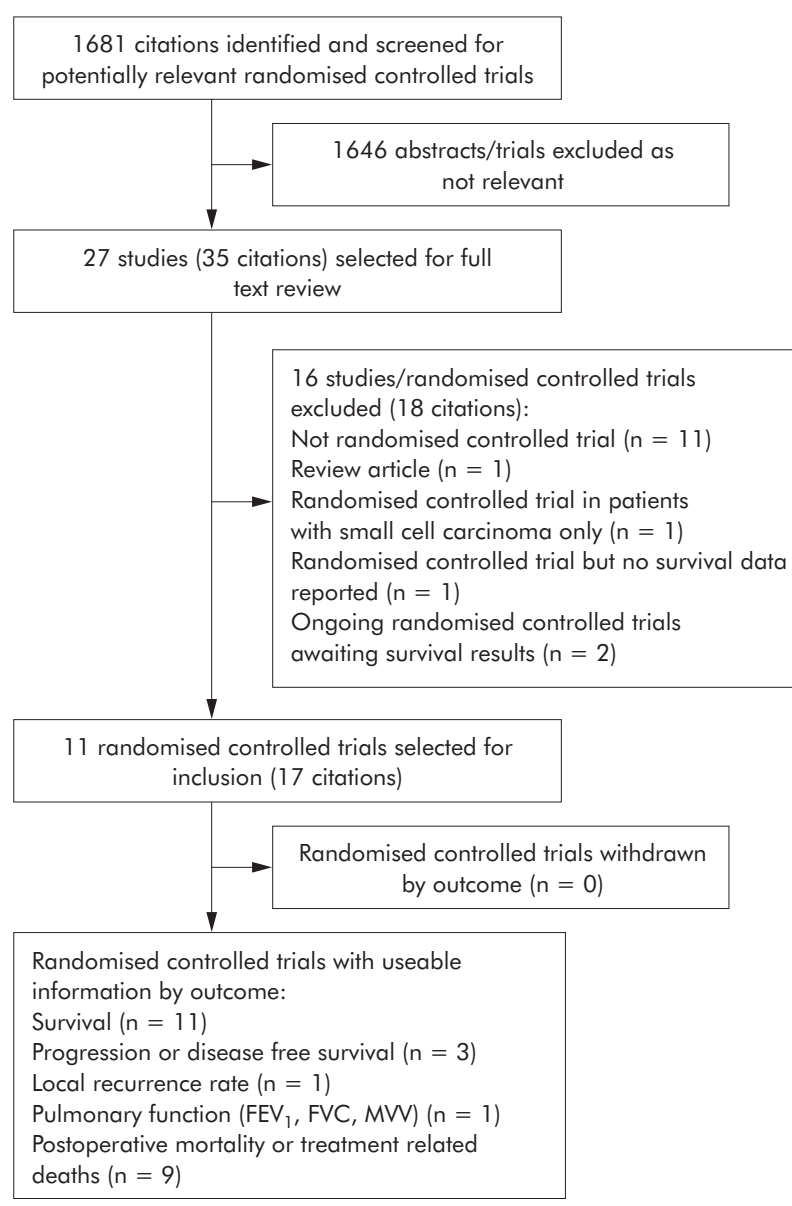

Figure 1 Results of search for trials and reasons for excluding trials. statistical heterogeneity, a fixed effects model was used for the pooled analysis.

Because of the broad inclusion criteria it was inappropriate to pool results for all studies. A pooled analysis was conducted on three trials comparing complete mediastinal lymph node dissection (CMLND) with systematic sampling (SS) of nodes. ${ }^{13-15}$ A separate pooled analysis was planned on trials comparing chemotherapy plus surgery with sequential chemotherapy plus radiotherapy in patients with stage IIIA NSCLC. ${ }^{16}{ }^{17}$ For the meta-analysis of survival data, the pooled log hazard ratio was calculated as a weighted average of the individual trial log hazard ratios, with weights inversely proportional to the variance of the log hazard ratio of each trial using the Review Manager software. ${ }^{18}{ }^{19}$ None of these studies reported a hazard ratio and variance that would be suitable for meta-analysis. The methods described by Parmar et al were used to estimate the hazard ratios and variance indirectly from confidence intervals or $\mathrm{p}$ values for the $\log$ rank test. ${ }^{18}$ For one study the hazard ratio was extracted from the survival curves using the methods of Parmar et al..$^{14}$ Briefly, in this case the time axis of the survival curve was split into equal non-overlapping time periods and the log hazard ratio was estimated for each equal time period and then combined in a stratified way across intervals to obtain an overall log hazard ratio. For a further study the authors ${ }^{16}$ provided original data enabling hazard ratio and variance calculation using the Cox proportional hazards model (Stata Version 6.0 for Windows, Stata Corporation, Texas, 1999).

For the meta-analysis of studies comparing complete mediastinal lymph node dissection with systematic sampling of mediastinal lymph nodes, follow up for two of the trials was restricted to 4 years so that the time periods of follow up would be comparable between pooled studies. ${ }^{14}{ }^{15}$ For the remaining studies a hazard ratio was calculated where possible; otherwise, survival at 2, 3, 4 or 5 years (depending on the data reported for the primary studies) was assessed by entering the number of participants surviving in Review Manager, but a pooled analysis was not conducted..$^{13}$ Where possible, the statistical analysis was conducted in accordance with intention to treat principles. The level of agreement between reviewers evaluating studies for inclusion was assessed using simple kappa statistics.

\section{RESULTS}

\section{Search for trials}

1181 citations were identified by the MEDLINE search, 70 by searching the Cochrane Central Register of Controlled Trials, and approximately 430 citations were identified by the EMBASE search. After review of abstracts selected from the search of electronic databases, bibliographies and hand searches, 27 papers were selected for full text review. Eleven trials (some with multiple citations) were selected for inclusion in the review. ${ }^{13-17} 20-28$ One of these controlled trials was not described as randomised in the report but the primary author confirmed that the study was randomised. ${ }^{16}$ No trials were identified that included an untreated control group. Ongoing trials were also identified but results are not yet available. ${ }^{29-31}$ Two reviewers (RM and GW) agreed on the studies to be included in all but one case (kappa statistic 0.93). The results of the search are outlined in fig 1 . No additional studies were identified by contacting the authors of primary studies or experts.

\section{Study characteristics}

Trials comparing surgery ( \pm other treatment) with non-surgical treatment arm

Several trials with diverse study designs were included in this category (table 1). Two trials compared chemotherapy followed by surgery with chemotherapy followed by 
Table 1 Trials comparing surgery ( \pm other treatment) with non-surgical treatment arm

\begin{tabular}{|c|c|c|c|c|c|}
\hline Study (year) & Subjects & Intervention & Control & $\begin{array}{l}\text { Number } \\
\text { randomised }\end{array}$ & Outcomes \\
\hline MRC, UK $(1954-8)^{25}$ & $\begin{array}{l}\text { Histologically confirmed, } \\
\text { clinically locoregional lung } \\
\text { cancer* }^{*}\end{array}$ & $\begin{array}{l}\text { Thoracotomy and radical } \\
\text { resection of tumour with hilar } \\
\text { and mediastinal nodes }\end{array}$ & $\begin{array}{l}\text { Radiotherapy ( } 45 \text { Gy to } \\
\text { primary and mediastinum) }\end{array}$ & 58 & $\begin{array}{l}\text { Overall } 4 \text { year } \\
\text { survival }\end{array}$ \\
\hline $\mathrm{NCl}$, USA $(1963-6)^{27}$ & $\begin{array}{l}\text { Histologically confirmed } \\
\text { inoperable locally advanced } \\
\text { lung cancer, }{ }^{*} \text { potentially } \\
\text { operable after radiotherapy }\end{array}$ & $\begin{array}{l}\text { Radiotherapy ( } 40 \text { Gy to primary } \\
\text { and mediastinum) followed by } \\
\text { surgery }\end{array}$ & $\begin{array}{l}\text { Radiotherapy only ( } 40 \mathrm{~Gy} \\
\text { to primary and } \\
\text { mediastinum) }\end{array}$ & $\begin{array}{l}425 \text { inoperable } \\
\text { patients given } \\
\text { radiotherapy, } \\
152 \text { randomised }\end{array}$ & $\begin{array}{l}\text { Overall and } \\
\text { disease free } 5 \text { year } \\
\text { survival }\end{array}$ \\
\hline $\begin{array}{l}\text { National Cancer Institute of } \\
\text { Canada Clinical Trials Group } \\
\text { (before 1997) } \text { (be }^{26}\end{array}$ & $\begin{array}{l}\text { Stage IIIA NSCLC (pN2) fit } \\
\text { for surgery, ECOG } \leqslant 2 \dagger\end{array}$ & $\begin{array}{l}\text { Induction chemotherapy followed } \\
\text { by surgical resection }\end{array}$ & $\begin{array}{l}\text { Radiotherapy ( } 60 \text { Gy total, } \\
50 \text { Gy to primary tumour } \\
\text { and mediastinum, plus } \\
10 \text { Gy to reduced target } \\
\text { volume) }\end{array}$ & 31 & $\begin{array}{l}\text { Overall } 2 \text { year } \\
\text { survival }\end{array}$ \\
\hline $\begin{array}{l}\text { RTOG§ 89-01 trial, USA } \\
(1990-4)^{17} \ddagger\end{array}$ & T1-T3 pN2MO NSCLC & $\begin{array}{l}\text { Induction cisplatin based } \\
\text { chemotherapy followed by } \\
\text { surgical resection }\end{array}$ & $\begin{array}{l}\text { Induction cisplatin based } \\
\text { chemotherapy followed by } \\
\text { radiotherapy ( } 64 \mathrm{~Gy} \text { ) }\end{array}$ & $\begin{array}{l}73 \text { given induction } \\
\text { chemotherapy, } 61 \\
\text { randomised }\end{array}$ & $\begin{array}{l}\text { Overall } 4 \text { year } \\
\text { survival }\end{array}$ \\
\hline $\begin{array}{l}\text { University of Athens, Greece, } \\
(1998-91)^{16} \ddagger\end{array}$ & $\begin{array}{l}\text { Stage IIIA NSCLC (exact } \\
\text { TNM not stated) Karnofsky } \\
\text { performance status } 70-90\end{array}$ & $\begin{array}{l}4 \text { cycles cisplatin based } \\
\text { chemotherapy followed by } \\
\text { surgical resection }\end{array}$ & $\begin{array}{l}6 \text { cycles of cisplatin based } \\
\text { chemotherapy followed by } \\
\text { radiotherapy ( } 50 \mathrm{~Gy} \text { ) }\end{array}$ & 40 & $\begin{array}{l}\text { Overall } 5 \text { year } \\
\text { survival }\end{array}$ \\
\hline $\begin{array}{l}\text { North American Intergroup } \\
\text { trial 0139 (RTOG 93-09), } \\
(1994-2001)^{20}\end{array}$ & $\begin{array}{l}\text { T1-3 pN2MO NSCLC, } \\
\text { surgical resection technically } \\
\text { feasible at randomisation }\end{array}$ & $\begin{array}{l}\text { Concurrent cisplatin and } \\
\text { etoposide and radiotherapy } \\
\text { ( } 45 \mathrm{~Gy} \text { ) followed by surgical } \\
\text { resection }\end{array}$ & $\begin{array}{l}\text { Concurrent cisplatin and } \\
\text { etoposide and radiotherapy } \\
\text { (61 Gy) }\end{array}$ & 429 & $\begin{array}{l}\text { Progression free } \\
\text { and overall } 3 \text { year } \\
\text { survival }\end{array}$ \\
\hline \multicolumn{6}{|c|}{$\begin{array}{l}\text { *Includes some cases of small cell lung cancer. } \\
\text { †ECOG, Eastern Cooperative Oncology Group performance status ( } 0=\text { asymptomatic, } 1=\text { capable of light work, } 2=\text { less then half daylight hours in bed). } \\
\text { †Trial closed prematurely. } \\
\text { §RTOG, Radiation Therapy Oncology Group. }\end{array}$} \\
\hline
\end{tabular}

radiotherapy in patients with stage IIIA NSCLC. In one study the inclusion criteria included the demonstration of pathological N2 disease ${ }^{17}$ but the TNM status of participants was not well described in the other study. ${ }^{16}$

\section{Studies comparing different surgical approaches for lung cancer \\ Mediastinal lymphadenectomy ( $n=3$ studies)}

Three studies compared CMLND with SS in patients with resectable NSCLC. ${ }^{13-15}$ Two of these were conducted in patients with resectable stages I-IIIA. ${ }^{13} 15$ One was limited to patients with peripheral NSCLC less than $2 \mathrm{~cm}$ in diameter and without evidence of metastasis. ${ }^{14}$ For this review the terminology recommended by Keller has been used..$^{30}$ SS refers to the routine biopsy of lymph nodes at the levels specified by the authors and CMLND refers to the routine removal of all ipsilateral lymph node bearing tissue. Further details are shown in table 2. One reviewer (GW) determined that SS was performed in similar fashion in the three studies, and CMLND was performed according to the techniques of Naruke et al and Martini et al. ${ }^{32}{ }^{33}$ In these studies patients with involvement of $\mathrm{N} 2$ nodes were offered adjuvant

Table 2 Trials comparing different surgical approaches for lung cancer

\begin{tabular}{|c|c|c|c|c|c|}
\hline Study and year & Subjects & Intervention & Control & $\begin{array}{l}\text { Number } \\
\text { randomised }\end{array}$ & Outcomes \\
\hline $\begin{array}{l}\text { Yamaguchi University, Japan } \\
(1993-4)^{24}\end{array}$ & $\begin{array}{l}\text { Clinical stage IA NSCLC, } \\
\text { no mediastinoscopy }\end{array}$ & $\begin{array}{l}\text { Video-assisted } \\
\text { thoracoscopic lobectomy }\end{array}$ & $\begin{array}{l}\text { Thoracotomy and } \\
\text { conventional lobectomy }\end{array}$ & 100 & Overall 5 year survival \\
\hline $\begin{array}{l}\text { Lung Cancer Study Group Trial, } \\
\text { North America }(1982-8)^{22}\end{array}$ & $\begin{array}{l}\text { TINOMO peripheral } \\
\text { NSCLC fit for lobectomy }\end{array}$ & $\begin{array}{l}\text { Limited resection (wedge } \\
\text { resection or segmentectomy, } \\
\text { i.e. less than lobectomy) }\end{array}$ & Conventional lobectomy & 276 & $\begin{array}{l}\text { Overall } 5 \text { year survival, local } \\
\text { recurrence rate, death with } \\
\text { cancer rate, pulmonary } \\
\text { function }\end{array}$ \\
\hline $\begin{array}{l}\text { University of Munich and Central } \\
\text { Hospital, Gauting, Germany } \\
(1989-91)^{13}\end{array}$ & $\begin{array}{l}\text { Resectable NSCLC } \\
\text { (stages I-IIIA) }\end{array}$ & $\begin{array}{l}\text { Thoracotomy, surgical } \\
\text { resection, complete } \\
\text { mediastinal lymph node } \\
\text { dissection }\end{array}$ & $\begin{array}{l}\text { Thoracotomy, surgical } \\
\text { resection, systematic } \\
\text { sampling } \\
\text { of mediastinal lymph } \\
\text { nodes }\end{array}$ & 201 & $\begin{array}{l}\text { Overall and progression free } \\
\text { survival (median follow up } \\
47 \text { months) }\end{array}$ \\
\hline $\begin{array}{l}\text { Yamaguchi University, Japan } \\
(1985-92)^{1 / 4}\end{array}$ & $\begin{array}{l}\text { Peripheral NSCLC } \\
<2 \mathrm{~cm} \text { diameter, } \\
\text { mediastinal and hilar } \\
\text { lymph nodes }<1 \mathrm{~cm} \text { on } \\
\mathrm{CT} \text { (no mediastinoscopy) }\end{array}$ & $\begin{array}{l}\text { Thoracotomy, surgical } \\
\text { resection, complete } \\
\text { mediastinal lymph node } \\
\text { dissection }\end{array}$ & $\begin{array}{l}\text { Thoracotomy, surgical } \\
\text { resection, systematic } \\
\text { sampling } \\
\text { of mediastinal lymph } \\
\text { nodes }\end{array}$ & 115 & Overall 5 year survival \\
\hline $\begin{array}{l}\text { Sun Yat-Sen University of Medical } \\
\text { Sciences, Guangzhou, China } \\
(1989-95)^{15}\end{array}$ & $\begin{array}{l}\text { Pathologically confirmed } \\
\text { NSCLC, clinical stages } \\
\text { I-IIIA, age }<71 \text { years }\end{array}$ & $\begin{array}{l}\text { Thoracotomy, surgical } \\
\text { resection, complete } \\
\text { mediastinal lymph node } \\
\text { dissection }\end{array}$ & $\begin{array}{l}\text { Thoracotomy, surgical } \\
\text { resection, systematic } \\
\text { sampling } \\
\text { of mediastinal lymph } \\
\text { nodes }\end{array}$ & 532 & Overall 5 year survival \\
\hline
\end{tabular}


Table 3 Methodological quality of included trials

\begin{tabular}{|c|c|c|c|c|c|}
\hline Study & $\begin{array}{l}\text { Allocation } \\
\text { concealment }\end{array}$ & $\begin{array}{l}\text { Method of } \\
\text { randomisation }\end{array}$ & $\begin{array}{l}\text { Blinded assessment } \\
\text { of outcome }\end{array}$ & $\begin{array}{l}\text { Description of } \\
\text { withdrawals }\end{array}$ & $\begin{array}{l}\text { Intention to treat } \\
\text { analysis }\end{array}$ \\
\hline MRC, $\mathrm{UK}^{25}$ & Adequate & Not reported & None described & No description & Yes* \\
\hline $\mathrm{NCl}, \mathrm{USA}^{27}$ & Adequate & Not reported & None described & Yes & Yes \\
\hline $\begin{array}{l}\text { National Cancer Institute of Canada } \\
\text { trial, North America }\end{array}$ & Adequate† & Adequate $†$ & No & No losses $†$ & Yes† \\
\hline RTOG $\neq 89-01^{17}$ & Not reported & Not reported & None described & Incomplete description & No \\
\hline University of Athens, Greece ${ }^{16}$ & Not reported & Not reported & None described & No description & No \\
\hline $\begin{array}{l}\text { Intergroup } 0139 \text { trial (RTOG } ¥ \\
93-09 \text { ), North America }\end{array}$ & Not reported & Not reported & None described & Incomplete description & No \\
\hline $\begin{array}{l}\text { Yamaguchi University } \\
\text { (VATS } v \text { open) }^{24}\end{array}$ & Inadequate & Inadequate & None described & No lossest & No \\
\hline $\begin{array}{l}\text { Lung Cancer Study Group trial, } \\
\text { North America }\end{array}$ & Adequate & Not reported & None described & $\begin{array}{l}\text { Yes (N.B. } 18 \% \text { loss in } \\
\text { each group) }\end{array}$ & Unclear \\
\hline University of Munich ${ }^{13}$ & Adequate $†$ & Adequate & Yes§ & Yes & No \\
\hline Yamaguchi University ${ }^{14}$ & Adequate $†$ & Adequate & None described & Yes & Yes \\
\hline $\begin{array}{l}\text { Sun Yat-Sen University of Medical } \\
\text { Sciences, Guangzhou }\end{array}$ & Adequate $†$ & Adequate $†$ & None described & Yes & No \\
\hline $\begin{array}{l}\text { *Unclear if losses to follow up. } \\
\text { †Confirmed by contacting authors. } \\
\text { †RTOG, Radiation Therapy Oncology } \\
\text { §lnvestigators undertaking follow up b }\end{array}$ & $\begin{array}{l}\text { Group. } \\
\text { linded from t }\end{array}$ & & & & \\
\hline
\end{tabular}

radiotherapy to the mediastinum postoperatively; however, in one study patient uptake in those with N2 disease in both arms was only about $30 \%$ according to the author. ${ }^{15}$

\section{Limited resection (wedge excision or segmentectomy) versus lobectomy}

In a multi-institutional North American study, individuals with proven or suspected TINO peripheral NSCLC were randomised to either limited resection (thoracotomy with wedge resection or segmentectomy) or lobectomy. ${ }^{22}$ All patients were able to tolerate a lobectomy as assessed by cardiopulmonary function. Sublobar resections of up to three segments or wedge resections encompassing the tumour and $2 \mathrm{~cm}$ of lung were allowed, at the surgeon's discretion. Pathological stage was confirmed before randomisation at the time of surgery by frozen section. After resection the completeness of resection was assessed by frozen section and clinically and, if the resection was incomplete or the tumour was found to be of a higher stage, the surgeon was required to complete the lobectomy. 276 were randomised at the time of surgery but there were 29 exclusions after randomisation. ${ }^{22}$

\section{Video assisted thoracoscopic surgery (VATS) lobectomy versus conventional lobectomy}

One study compared 5 year survival in patients randomised to VATS lobectomy versus conventional lobectomy in patients with clinical stage IA NSCLC. ${ }^{24}$

\section{Quality of included trials}

In the three studies of CMLND versus SS allocation concealment and method of randomisation were found to be adequate (in some cases after contact with the authors). ${ }^{13-15}$ Further quality details of the trials are shown in table 3. None of the included studies contained a clear statement that they had conducted an intention to treat analysis. However, this information was inferred from information provided about analysis and results for some of the trials. For two trials there were no crossovers after

Table 4 Overall survival and progression free survival for trials comparing surgery $( \pm$ other treatment) with non-surgical treatment

\begin{tabular}{|c|c|c|c|}
\hline Study & Arm 1 & Arm 2 & $\operatorname{RR}(95 \% \mathrm{Cl})$ \\
\hline \multirow[t]{3}{*}{ MRC, $U^{25}$} & Surgery & Radiotherapy & \\
\hline & 4 year OS $23 \%$ & 4 year OS $7 \%$ & $3.27(0.74$ to 14.42$), p=0.12$ \\
\hline & $\begin{array}{l}\text { Squamous cell subgroup } \\
\text { analysis } 30 \%\end{array}$ & $\begin{array}{l}\text { Squamous cell subgroup } \\
\text { analysis } 6 \%\end{array}$ & $5.10(0.68$ to 38.29$), p=0.11$ \\
\hline \multirow[t]{4}{*}{$\mathrm{NCl}, \mathrm{USA}^{27}$} & $\begin{array}{l}\text { Initially inoperable, } \\
\text { radiotherapy }\end{array}$ & $\begin{array}{l}\text { Initially inoperable, } \\
\text { radiotherapy }\end{array}$ & \\
\hline & Surgery & No surgery & \\
\hline & 5 year OS $8 \%$ & 5 year OS $6 \%$ & $1.42(0.42$ to 4.81$), p=0.57$ \\
\hline & 5 year PFS $6 \%$ & 5 year PFS $4 \%$ & $1.58(0.39$ to 6.38$), p=0.52$ \\
\hline $\begin{array}{l}\text { National Cancer Institute } \\
\text { of Canada, North }\end{array}$ & $\begin{array}{l}\text { Chemotherapy then } \\
\text { surgery }\end{array}$ & Radiotherapy & \\
\hline America $^{26}$ & 2 year OS $44 \%$ & 2 year OS $40 \%$ & $1.09(0.48$ to 2.51$)$ \\
\hline \multirow[t]{4}{*}{$\begin{array}{l}\text { Intergroup } 0139 \text { trial } \\
\text { (RTOG 93-09), North } \\
\text { America }^{20}\end{array}$} & $\begin{array}{l}\text { Concurrent chemotherapy } \\
\text { and radiotherapy then } \\
\text { surgery }\end{array}$ & $\begin{array}{l}\text { Concurrent chemotherapy } \\
\text { and radiotherapy }\end{array}$ & 1.53 \\
\hline & Treatment deaths 14 & Treatment deaths 3 & $4.43(1.29$ to 15.19$), p=0.02$ \\
\hline & 3 year PFS 29\% & 3 year PFS 19\% & (1.06 to 2.21$), p=0.02$ \\
\hline & 3 year OS $38 \%$ & 3 year OS $33 \%$ & $1.16(0.89$ to 1.52$), p=0.27$ \\
\hline
\end{tabular}

OS, overall survival; PFS, progression free survival; RTOG, Radiation Therapy Oncology Group; RR, relative risk; Cl, confidence interval. 


\begin{tabular}{|c|c|c|c|c|}
\hline \multirow{2}{*}{$\frac{\text { Study }}{\text { Stathopoulos } 1996}$} & Reference & $\begin{array}{c}\log [\text { Hazard ratio }] \\
(\mathrm{SE})\end{array}$ & $\begin{array}{l}\text { Hazard ratio (random) } \\
\qquad 95 \% \mathrm{Cl}\end{array}$ & $\begin{array}{l}\text { Hazard ratio (random } \\
95 \% \mathrm{Cl}\end{array}$ \\
\hline & 16 & $1.0950(0.3592)$ & $\longrightarrow$ & $2.99(1.48,6.04)$ \\
\hline Johnstone 2002 & 17 & $0.2150(0.2886)$ & - & $1.24(0.70,2.18)$ \\
\hline \multicolumn{5}{|c|}{$\begin{array}{l}\text { Test for heterogeneity: } \mathrm{Chi}^{2}=3.65, \mathrm{df}=1(\mathrm{P}=0.06), \\
\mathrm{I}^{2}=72.6 \%\end{array}$} \\
\hline & & & 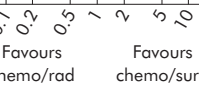 & \\
\hline
\end{tabular}

Figure 2 Hazard ratio (4 year survival) for studies comparing chemotherapy plus radiotherapy with chemotherapy plus surgery in patients with respectable stage IIIA NSCLC. The squares represent the hazard ratios for the individual trials and the line represents the corresponding $95 \%$ confidence intervals. () Cochrane Library (reproduced with permission).

randomisation but there were a number of exclusions after randomisation, not strictly adhering to intention to treat analysis. ${ }^{11} 1315$

\section{Data synthesis}

Trials comparing surgery ( \pm other treatment) with non-surgical treatment arm

The results of four trials included in this category are shown in table $4 .^{20}{ }^{25-27}$ These trials were diverse in terms of the interventions and populations and therefore not suitable for pooled analysis. In none of the studies was the surgical treatment arm found to be significantly superior to the nonsurgical group in terms of overall survival. The authors intended to conduct a pooled analysis of the two studies comparing chemotherapy followed by surgery with chemotherapy followed by radiotherapy but there was significant statistical heterogeneity between these studies $\left(\chi^{2}\right.$ statistic for homogeneity 3.65, $\mathrm{p}=0.06$ ) so a pooled analysis was not performed. The results of these individual studies are shown in fig 2 . In one study there were two treatment related deaths in the chemotherapy/surgery group and one in the chemotherapy/radiotherapy group (relative risk (RR) 2.21 (95\% CI 0.21 to 23.08$), \mathrm{p}=0.51) .{ }^{17}$ Treatment related deaths were not described in the other trial. ${ }^{16}$

\section{Studies comparing different surgical approaches for lung cancer \\ Mediastinal lymphadenectomy}

A pooled analysis (fixed effects model) was conducted comparing hazards (or mortality rate) over the first 4 years after randomisation for the three studies included in this category. There was a significant reduction in the risk of death in the group undergoing CMLND (fig 3) with a pooled hazard ratio estimated at 0.78 (95\% CI 0.65 to 0.93 ; $\mathrm{p}=0.005$ ). There was no significant statistical heterogeneity between studies being pooled $\left(\chi^{2}\right.$ statistic $\left.=0.13 ; p=0.94\right)$. A subgroup analysis by stage was not conducted due to the possibility of stage migration in the CMLND group (Will Rogers phenomenon). ${ }^{34}$ In one trial there was a nonsignificant trend to improved disease free survival in the CMLND group with a median follow up of 47.5 months; the hazard ratio was reported to be 0.82 (95\% CI 0.54 to 1.27$).{ }^{13}$ The remaining trials did not report time to event data for disease recurrence so meta-analysis was not possible.

None of the trials individually found a significant difference between the groups in terms of 30 day operative mortality. In the pooled analysis the relative risk was 0.86 (95\% CI 0.19 to $3.77, \mathrm{p}=0.84$ ) without significant statistical heterogeneity between studies being pooled $(\mathrm{p}=0.39)$.

Limited resection versus lobectomy

In the study comparing limited resection with lobectomy in patients with peripheral stage I NSCLC, limited resection was

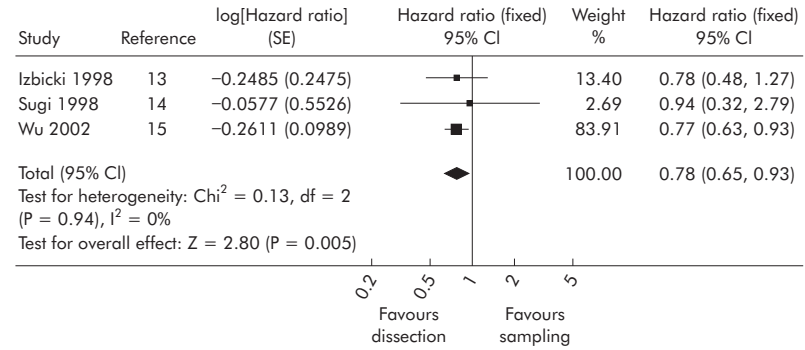

Figure 3 Hazard ratio (4 year survival) for studies comparing complete mediastinal lymph node dissection with mediastinal node sampling. For the individual trials the squares represent the hazard ratios and the line represents the $95 \%$ confidence intervals. The diamond represents the results of the pooled analysis using the fixed effect model. ${ }^{\circ}$ Cochrane Library (reproduced with permission).

associated with an increased risk of locoregional recurrence (RR 2.84 (95\% CI 1.32 to 6.1), p = 0.007)..$^{22}{ }^{23}$ There was also a trend to improved overall survival with 5 year survival of $74 \%$ in the lobectomy group and $55 \%$ in the limited resection group. ${ }^{24}$ The hazard ratio was 0.67 (95\% CI 0.44 to 1.02 , $\mathrm{p}=0.062$ ). There was a trend to an increased mortality rate from cancer in the limited resection group compared with the lobectomy group (RR 1.46 (95\% CI 0.87 to 2.45 ), p = 0.15). It is not clear if the results presented above were based on an intention to treat analysis; however, the investigators involved in the Lung Cancer Study Group trial also conducted an analysis that included all patients randomised but actual results were not provided in the published report. ${ }^{22}{ }^{23}$ There was less reduction (from the preoperative level) in forced expiratory volume in 1 second at 12-18 months (mean \% difference) in the limited resection group than in the lobectomy group. The mean difference between groups was $5.91(95 \%$ CI 0.29 to $11.53, p=0.04)$. However, this difference is of doubtful clinical significance and, furthermore, less than $67 \%$ of participants had lung function results available at 12-18 months. There were two postoperative deaths in the lobectomy group and one in the limited resection group, but these figures were for all 276 individuals randomised and it was not clear from the report ${ }^{22}$ what the denominator was for each group.

\section{VATS lobectomy versus conventional lobectomy}

In the one study in this category the 5 year survival rate was $85 \%$ in the open group and $90 \%$ in the VATS group (RR 1.09 (95\% CI 0.91 to $1.23, \mathrm{p}=0.46) .{ }^{24}$

\section{DISCUSSION}

Eleven trials with a total of 1910 patients were included in this review. No studies were identified comparing surgery alone with a no treatment arm. Only one study included patients with local and locoregional NSCLC and compared surgery alone with radiotherapy alone. ${ }^{25}$ However, although there was a trend to improved survival in the subgroup with squamous cell carcinoma in this study, this did not reach statistical significance in our analysis. ${ }^{26}$ The review also shows that the role of surgery in combined modality treatment for stage IIIA NSCLC is unclear. One study comparing chemotherapy followed by surgery with sequential chemotherapy and radiotherapy was inconclusive because of small numbers. ${ }^{17}$ A similar study found in favour of chemotherapy plus surgery compared with sequential chemotherapy and radiotherapy in stage IIIA disease. However, the results were not based on intention to treat analysis and it is possible that an imbalance between unknown prognostic factors could have occurred in this small study. ${ }^{16}$ 
Although the Lung Cancer Study Group trial showed that there was a significant increase in local recurrence in the limited resection group, the trend to a reduction in the rate of death with cancer and death from all causes in the lobectomy group did not reach statistical significance at the conventional 5\% level..$^{22}$ The study was designed to show equivalence between the two groups and therefore a more conservative $p$ value of $\mathrm{p}>0.1$ was used as acceptable evidence of equivalence. However, the $95 \%$ confidence intervals for the hazard ratio for 5 year overall survival are wide (0.44 to 1.02) and encompass equivalence. Likewise, they do not exclude a clinically important difference between the two groups.

The results of studies comparing CMLND with SS are of particular interest with respect to the efficacy of surgery in general and future surgical practice. In the pooled analysis of the three studies there was a significant reduction in death from all causes in the group undergoing CMLND. These results suggest that the risk of dying on any given day (given survival to that point) is $78 \%$ (95\% CI 65 to 93 ) for the CMLND group compared with the SS group.

The quality of the primary studies should be taken into account when interpreting the results of this review. Several studies in this review have some methodological weaknesses that represent serious threats to the validity of the findings. ${ }^{22} 24$ In particular, the Lung Cancer Study Group trial reported high rates of losses to follow up in both groups and did not clearly state whether patients were analysed according to treatment received or treatment assigned. ${ }^{22}$ In addition, blinded assessment of outcome was not undertaken in this study and the high local recurrence rate in the limited resection group could, to some extent, reflect a detection bias. Furthermore, several trials excluded participants after randomisation in a manner that would not strictly fulfil the criteria for an intention to treat analysis. ${ }^{12}{ }^{13}{ }^{15}$ It is difficult to draw any conclusions about the role of VATS versus conventional lobectomy because the only study included in this review was small and the analysis was not by intention to treat. ${ }^{24}$

Few trials included in this review have described the experience of the surgeons involved in performing surgery. The efficacy of the intervention may be influenced by the experience of the surgeons. ${ }^{35}$ This information is required when making judgements about the generalisability of any findings.

In summary, the current evidence from RCTs neither supports nor discounts the survival benefit of surgery for NSCLC. However, as more extensive (complete) surgery appears superior to less, by inference some surgery might be better than no surgery. In particular, compared with limited resection, lobectomy was shown to reduce the rate of local recurrence in individuals with stage I NSCLC in one study. CMLND appears to improve survival compared with SS in individuals with resected NSCLC. The results of the American College of Surgeons Oncology Group Z30 trial will be important to further clarify this issue. ${ }^{30}$ Similarly, the results of ongoing trials should help to clarify the role of surgery following induction chemotherapy with or without radiotherapy for patients with stage IIIA (N2) NSCLC. ${ }^{20}{ }^{29}$ Further details of ongoing trials identified by this review are outlined elsewhere. ${ }^{8}$ If ongoing trials show that surgery does not significantly improve survival after induction chemotherapy with or without radiotherapy in patients with stage IIIA (N2) NSCLC, then it may be reasonable to conduct further RCTs comparing surgery with radiotherapy or chemoradiation in selected groups of patients with earlier stage NSCLCfor example, in older patients in whom the perioperative mortality of surgery is on average $6 \%$ for patients aged 70 79 years and $8 \%$ for those aged 80 years and older, ${ }^{36}$ or in patients with reduced respiratory reserve.

\section{ACKNOWLEDGEMENTS}

The authors thank the Iberoamerican Cochrane Center for assistance with database searches and Dr Sera Tort, Dr Marta Roque and Dr Elinor Thompson (coordinators of the Cochrane Lung Cancer Group) for assistance with protocol development and editing of the review. They also acknowledge the help provided by authors of primary studies who have responded to correspondence and provided additional information. Some of the narrative in the text, tables 1 , 2 and 3, and figures 2 and 3 of the present article also appear in the Cochrane Review ( ${ }^{\circ}$ Cochrane Library, reproduced with permission).

\section{Authors' affiliations}

G Wright, Cardiothoracic Care Centre, St Vincent's Hospital Melbourne, Fitzroy, Victoria, Australia

R L Manser, D Hart, Department of Respiratory Medicine, St Vincent's Hospital Melbourne, Fitzroy, Victoria, Australia

R L Manser, Clinical Epidemiology and Health Service Evaluation Unit, Royal Melbourne Hospital, Parkville, Victoria, Australia

G Byrnes, Centre for Genetic Epidemiology, The University of

Melbourne, Parkville, Victoria, Australia

D A Campbell, Monash Institute of Health Services Research, Monash Medical Centre, Clayton, Victoria, Australia

Dr Manser is supported by an Australian National Health and Medical Research Council postgraduate scholarship (scholarship number 201713).

Competing interests: none.

\section{REFERENCES}

1 Reif $M$, Socinski MA, Rivera MP. Evidence-based medicine in the treatment of non-small cell lung cancer. Clin Chest Med 2000;21:107-20.

2 Scott W, Howington J, Movsas B. Treatment of stage II non-small cell lung cancer. Chest 2003;123(Suppl 1):188-201S.

3 Smythe W. Treatment of stage I non-small cell lung carcinoma. Chest 2003; 123(Suppl 1):181-7S.

4 Flehinger BJ, Kimmel M, Melamed MR. The effect of surgical treatment on survival from early lung cancer. Implications for screening. Chest 1992;101:1013-8.

5 Sobue T, Suzuki T, Matsuda M, et al. Survival for clinical stage I lung cancer not surgically treated: comparison between screen-detected and symptomdetected cases. Cancer 1992;69:685-92.

6 Lederle F, Niewoehner DE. Lung cancer surgery: a critical review of the evidence. Arch Intern Med 1994;154:2397-401.

7 Jones D, Detterbeck FC. Surgery for stage I non-small cell lung cancer. In: Detterbeck F, Rivera MP, Socinski MA, Rosenman JG, eds. Diagnosis and treatment of lung cancer- an evidence based guide. Philadelphia: W B Saunders, 2001:177-90.

8 Manser R, Wright G, Hart D, et al. Surgery for early stage non-small cell lung cancer (Cochrane Review). In:The Cochrane Library, Issue 1. Chichester, UK: John Wiley \& Sons, 2005.

9 Clarke M, Oxman AD, eds. Cochrane reviewers' handbook 4.1. Oxford, UK: The Cochrane Collaboration, 2000.

10 Jadad A, Moore RA, Carroll D, et al. Assessing the quality of reports of randomised clinical trials: is blinding necessary? Control Clin Trials 1996;17:1-12.

11 Montori V, Guyatt GH. Intention-to-treat principle. Can Med Assoc J 2001; 165:1339-41.

12 Fergusson D, Aaron SD, Guyatt G, et al. Post-randomisation exclusions: the intention to treat principle and excluding patients from analysis. BMJ 2002;325:652-4.

13 Izbicki J, Passlick B, Pantel K, et al. Effectiveness of radical systematic mediastinal lymphadenectomy in patients with resectable non-small cell lung cancer: results of a prospective randomized trial. Ann Surg 1998;227:138-44.

14 Sugi K, Nawata K, Fujita N, et al. Systematic Lymph node dissection for clinically diagnosed peripheral non-small cell lung cancer less than $2 \mathrm{~cm}$ in diameter. World J Surg 1998;22:290-5.

15 Wu Y-I, Huang Z-F, Wang S-Y, et al. A randomised trial of systematic nodal dissection in resectable non-small cell lung cancer. Lung Cancer 2002;36:1-6.

16 Stathopoulos G, Papakostas P, Malamos NA, et al. Chemo-radiotherapy versus chemo-surgery in stage IIIA non-small cell lung cancer. Oncol Rep 1996;3:673-6.

17 Johnstone D, Byhardt RW, Ettinger D, et al. Phase III study comparing chemotherapy and radiotherapy with preoperative chemotherapy and surgical resection in patients with non-small cell lung cancer with spread to mediastinal lymph nodes (N2). Final report of RTOG 89-01. Int J Radiat Oncol Biol Phys 2002;54:365-9.

18 Parmar M, Torri V, Stewart L. Extracting summary statistics to perform metaanalyses of the published literature for survival endpoints. Stat Med 1998;17:2815-34.

19 Whitehead A, Whitehead J. A general parametric approach to the metaanalysis of randomised clinical trials. Stat Med 1991;10:1665-77. 
20 Albain K, Scott CB, Rusch VR, et al. Phase III study of concurrent chemotherapy and full course radiotherapy (CT/RT) versus CT/RT induction followed by resection for stage IIIA (pN2) NSCLC. Lung Cancer 2003;41(Suppl 2):S4.

21 Izbicki J, Passlick B, Karg O, et al. Impact of radical systematic mediastinal lymphadenectomy on tumour staging in lung cancer. Ann Thorac Surg 1995;59:209-14

22 Ginsberg R, Rubinstein LV, for the Lung Cancer Study Group. Randomised trial of lobectomy versus limited resection for T1NO non-small cell lung cancer. Ann Thorac Surg 1995;60:615-23.

23 Rubinstein L, Ginsberg RJ. Lobectomy versus limited resection in T1NO lung cancer. Ann Thorac Surg 1996;62:1249-50.

24 Sugi K, Kaneda Y, Esato K. Video-assisted thoracoscopic lobectomy achieves a satisfactory long term prognosis in patients with clinical stage $1 \mathrm{~A}$ lung cancer. World J Surg 2000;24:27-31.

25 Morrison R, Deeley TJ, Cleland WP. The treatment of carcinoma of the bronchus: a clinical trial to compare surgery and supervoltage radiotherapy. Lancet 1963;1:683-4.

26 Shepherd F, Johnston MR, Payne D, et al. Randomised study of chemotherapy and surgery versus radiotherapy for stage IIIA non-small-cell lung cancer: a National Cancer Institute of Canada Clinical Trials Group Study. Br J Cancer 1998;78:683-5.

27 Warram J, on behalf of collaborating investigators. Preoperative irradiation of cancer of the lung: final report of a therapeutic trial (a collaborative study). Cancer 1975;36:914-25.

28 Warram J, on behalf of collaborating investigators. Preoperative irradiation of cancer of the lung: preliminary report of a therapeutic trial (a collaborative study). Cancer 1969;23:419-29.
29 Splinter T, van Schil PE, Kramer GWPM, et al. Randomised trial of surgery versus radiotherapy in patients with stage IIIA (N2) non-small cell lung cancer after response to induction chemotherapy (EORTC 08941). Clin Lung Cancer 2000;2:69-72

30 Keller S. Complete mediastinal lymph node dissection - does it make a difference? Lung Cancer 2002;36:7-8.

31 Allen M, for the American College of Surgeons Oncology Group (Thoracic Organ Site Committee). Randomised trial of mediastinal lymph node sampling versus complete lymphadenectomy during pulmonary resection in patients with NO or N1 (less than hilar) non-small cell lung cancer. Available at http:// www.acosog.org/studies/synopses/ZO030_Synopsis.pdf (accessed October 2004).

32 Naruke T, Suemasu K, Ishikawa S. Surgical treatment for lung cancer with metastasis to mediastinal lymph nodes. J Thorac Cardiovasc Surg 1976:71:279-85.

33 Martini N, Flehinger BJ. The role of surgery in N2 lung cancer. Surg Clin North Am 1987;67:1037.

34 Feinstein A, Sosin DM, Wells CK. The Will Rogers phenomenon. Stage migration and new diagnostic techniques as a source of misleading statistics for survival in cancer. N Engl J Med 1985;312:1604-8.

35 Bach P, Cramer LD, Schrag D, et al. The influence of hospital volume on survival after resection for lung cancer. N Engl J Med 2001;345:181-8.

36 Kiser A, Detterbeck FC. General aspects of surgical treatment. In: Detterbeck F, Rivera MP, Socinski MA, Rosenman JG, eds. Diagnosis and treatment of lung cancer: an evidence based guide. Philadelphia: WB Saunders, 2001:133-47.

\section{LUNG ALERT}

High prevalence of PE in patients with unexplained exacerbation of COPD

$\Delta$ Tillie-Leblond I, Marquette CH, Perez T, et al. Pulmonary embolism in patients with unexplained exacerbation of chronic obstructive pulmonary disease: prevalence and risk factors. Ann Intern Med 2006;144:390-6

7 his single centre study enrolled 197 patients with COPD requiring admission to hospital for an unexplained acute exacerbation. Patients with any evidence of lower respiratory tract infection, pneumothorax, and those requiring invasive ventilation were excluded. Patients with clinical and radiological findings deemed out of keeping with the degree of hypoxaemia were included. All patients were investigated with computed tomogram pulmonary angiography (CTPA) and venous lower limb ultrasonography.

Evidence of pulmonary embolus (PE) was found in 49 of the 197 patients (25\%, 95\% CI 19 to 32). This is consistent with previously published data. The diagnosis of PE was determined by positive CTPA and deep vein thrombosis (DVT) on ultrasound in 19 patients; 24 patients had a positive CTPA alone and six with a negative CTPA had DVT seen on ultrasound. The patients were retrospectively categorised into low, intermediate, and high probability according to the Geneva score. Eleven of the 119 patients (9\%) in the low probability group had PE, 35 of 75 patients $(46 \%)$ in the intermediate probability category had PE, and all three in the high probability group had PE.

The diagnosis of PE could not therefore be excluded on the basis of a low probability Geneva score. The only reliable risk factors identified in this study group were previous thromboembolism, malignancy, and a decreased arterial carbon dioxide tension compared with baseline.

A Patel

Senior Clinical Fellow, Royal Free Hospital, London, UK; anantpatel478@yahoo.co.uk 